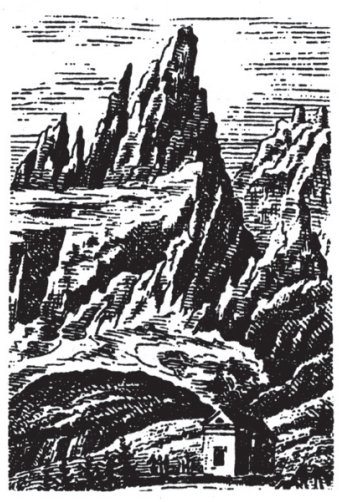

Dorota Heck

ORCID: 0000-0001-6825-7695

Uniwersytet Wrocławski

dorota.heck@gmail.com

dorota.heck@uwr.edu.pl

DOl: $10.19195 / 2084-4107.12 .21$

\title{
Wojciecha Kudyby Gorce Pana
}

Słowa-klucze: Wojciech Kudyba, poezja religijna, góry w poezji, Gorce, hermeneutyka Keywords: Wojciech Kudyba, religious poetry, mountains in poetry, Gorce, hermeneutics

\section{Wojciech Kudyba's Gorce Pana (Gorce of the Lord)}

\section{Summary}

In the 20th century religious poetry was mainly the domain of famous poet priests; today better known are secular authors from various generations, for example Zbigniew Jankowski, Wojciech Bonowicz, Krzysztof Koehler, Wojciech Wencel and Mirosław Dzień. Standing out with his avoidance of pathos and clarity of poetic diction, Wojciech Kudyba published his first book of poetry appreciated by literary critics, Tyszowce $i$ inne miasta (Tyszowce and other towns), thirteen years ago. It was followed in 2008 by Gorce Pana (Gorce of the Lord) - of key importance to the understanding of the role of the mountains in Kurdyba's poetic imagination - and Ojciec sie zmienia (The Father is changing) in 2011. The summa of the poet's oeuvre so far, a selection entitled W końcu świat (Finally the world), is divided into three parts: "Inne miasta" (Other towns), "Inne góry" (Other mountains) and "Kogo brak" (Who's missing). They correspond to his earlier volumes of poetry. The poet's own descriptions point to the considerable significance of a coherent composition of the collection. Repetitions of the various motifs resemble a rosary or a sequence of mirror reflections. Hermeneutic analyses of the various poems lead to a conclusion that har- 
mony, questioned by the possibility of self-irony, results in the effect of moved form, sought after by the poet, while literary geography, fascination with the mountains and respect for epiphany balance out the irony, stabilising the emphasis on the eternal harmony of the universe present in the beauty of Gorce.

Wojciech Kudyba jest nie tylko poetą, lecz także historykiem literatury polskiej XX wieku i znanym krytykiem. Urodził się 1965 roku na Lubelszczyźnie. Był uczniem prof. Stefana Sawickiego, teoretyka z Katolickiego Uniwersytetu Lubelskiego, czołowego przedstawiciela literaturoznawczej aksjologii oraz badacza twórczości Cypriana Norwida. Francuska krytyka tematyczna, krytyka archetypiczna i niedościgły wzór interpretatora (w postaci Jerzego Kwiatkowskiego) — to zdaniem Małgorzaty Czermińskiej wysoce prawdopodobne źródła metodologicznych inspiracji Kudyby, „prawdziwego znawcy i wielbiciela poezji”. Opublikował monografię Rana, która przyzywa Boga. O twórczości poetyckiej Janusza St. Pasierba (2006) oraz kilka zbiorów analiz i szkiców interpretacyjnych (na przykład Wiersze wobec Innego, 2012; Generacja źle obecna, 2014), wykładał w Krakowie, Nowym Targu i Warszawie, współredagował prasę literacką i periodyki naukowe, a za młodu zajmował się piśmiennictwem religijnym, w tym sądeckimi regionaliami, co nie jest bez znaczenia duchowego w kręgu promieniowania klasztoru sióstr klarysek związanego z postacią świętej Kingi.

Odkąd wydał swego rodzaju juwenilia na początku lat dziewięćdziesiątych, Kudyba-poeta zamilkł do powtórnego książkowego debiutu poetyckiego zatytułowanego Tyszowce i inne miasta (2005). Następnie co trzy lata ukazywały się nowości: Gorce Pana (2008) i Ojciec się zmienia (2011). Charakterystyczna była tu ciągłość rodzinnej tradycji, ścisły związek realiów w wierszach z motywami niejako „apokryfu rodzinnego" (by posłużyć się formułą zapożyczoną z prozy Hanny Malewskiej) samego poety. Sam autor zaznaczył w swym życiorysie: „To miejsca nas ustanawiają, organizują wyobraźnię. To one są czymś pierwotnym"2.

W 2015 roku objawił się nowy Kudyba-pisarz — prozaik, autor opatrzonej recenzją wydawniczą Aleksandra Fiuta i opublikowanej w Bibliotece „Więzi” powieści Nazywam się Majdan. Zademonstrował w niej niezwykły słuch językowy, opowiadając z humorem losy młodego stypendysty, który w naukowych peregrynacjach poznaje kulturę Ukrainy i Polski, zatrzymuje się na pograniczach, posługuje się angielszczyzną i niemczyzną, ale przecież nie umie tego, co kresowe staruszki - mistrzynie survivalu w stylu vintage... Tomasz Mizerkiewicz, Marta Kwaśnicka, Jacek Podgórski, Vira Andreichuk i Katarzyna Wójcik należeli do recenzentów, którzy zauważyli tę książkę. Obecnie ukazują się kolejne prozatorskie nowości omawianego autora (powieść Imigranci wracają do domu, zbiór opowiadań Kamienica), lecz przede wszystkim dał się on dotąd poznać jako poeta z grupy Topoi, skupionej wokół sopockiego - choć rangą ogólnopolskiego, a duchem europejskiego - dwumiesięcznika „Topos”.

${ }^{1}$ Cyt. za: W. Kudyba, Wiersze wobec Innego, Sopot 2012, s. 4 okładki.

2 W. Kudyba, W końcu świat, Sopot 2014, s. 108. 
Spośród krytyków literackich, którzy komentowali jeśli nie całą lirykę Kudyby, to przynajmniej poszczególne książki poetyckie, recenzowane jako nowości, są Tomasz Garbol, Grzegorz Kociuba, Marek Bernacki, a wyróżnić trzeba cieszącego się ogromnym autorytetem Jacka Łukasiewicza ${ }^{3}$. Wiele miejsca na wirtuozerskie analizy wierszy Kudyby poświęcił Adrian Gleń w swej ważnej książce krytycznoliterackiej Krytyka i metafizyka. Z kolei redaktor prasy literackiej i poeta Wojciech Kass zanotował:

Po powrocie z Nowego Sącza znów oddałem się lekturze pięknych wierszy Wojtka Kudyby z Gorców Pana. On też pochylił się nad tym źródłem, obmyte i mieniące się słowa puścił w tan i rytm, aby obracały się i wirowały w uścisku ze stworzeniem, które przemija i przemienia się w uścisku z Niepojętym ${ }^{4}$.

Poemat Topoi Kudyby wskazuje na główną inspirację filozoficzną jego twórczości - filozofię spotkania. Dystans poznawczy, sensualizm, delikatnie sygnalizowane poczucie humoru idealnie współgrają z poważnym sensem filozoficznym. Wiersze nadają się do typowo polonistycznych analiz intertekstualnych lub translatologicznych studiów porównawczych. Kilku wybitnych profesorów literatury współczesnej lub teorii literatury (by wymienić przykładowo w kolejności dat urodzenia: wspomniany już Jacek Łukasiewicz, Andrzej Sulikowski, Wojciech Ligęza, Zofia Zarębianka, Maciej Urbanowski), a nawet językoznawstwa (Jadwiga Puzynina) bardzo wysoko ocenili tę poezję. Stefan Sawicki spostrzegł w poezji autora Gorców Pana „symboliczny realizm”. O znaczeniu kategorii czystości w młodzieńczych tekstach Kudyby zajmujący się literaturą teolog, znawca poezji Czesława Miłosza, a także poeta Jerzy Szymik pisał:

lektura tej książki przypomina wpatrywanie się w głęboki, ale bardzo czysty staw, którego dno widać doskonale. Trzeba więc uważać, by tej przejrzystości nie zamącić. Wszak — jak się dowiadujemy — „być czystym" znaczy nie zasłaniać światła ${ }^{5}$.

Gorce Pana to tyleż tytuł tomiku poetyckiego, co stwierdzenie kulturowego faktu. Według Mircei Eliadego ${ }^{6}$ człowiek staje się sobą, dążąc do Boga; góry zaś stanowią zarówno teosferę, jak antroposferę i orosferę. Gorce należą do Boga (jak wszystko), ale należą w sposób szczególny w takim sensie, w jakim one same

${ }^{3}$ M. Bernacki, Caty świat Wojciecha Kudyby, „Topos” 2015, nr 2, s. 113-119; T. Garbol, Nastuchiwanie, „Topos” 2015, nr 1, s. 105-111; idem, Rehabilitacja literatury, „Ethos” 2013, nr 4, s. 317-320; G. Kociuba, Próba całości, „Fraza” 2015, nr 2, s. 117-120; J. Łukasiewicz, O wierszach Wojciecha Kudyby, pamflecie i upale, „Odra” 2014, nr 9, s. 84-85.

4 W. Kass, Ręka piszaca (1), [w:] Konstelacja Topoi o rzeczach najważniejszych, red. A. Gleń, Sopot 2017, s. 82 .

5 J. Szymik, Stowo do Czytelnika, [w:] W. Kudyba, Słowa bliskie, Kraków 2003, s. 5.

${ }^{6} \mathrm{O}$ dychotomicznym porządku sacrum i profanum zob. M. Eliade, Sacrum a profanum. O istocie sfery religijnej, przeł. B. Baran, Warszawa 2008, s. 12, 17-18, 27, 33, $59,66$.

${ }^{7}$ R. Rogowski, Mistyka gór, Wrocław 1983, s. 154. 
są szczególne: piękne, dawno wybrane na ludzkie siedziby, uświetnione historią, zwłaszcza chlubnymi dziejami literatury (w ich okolicach działali Seweryn Goszczyński, Władysław Orkan, a ostatnio kilku wybitnych poetów średniego pokolenia: Jan Polkowski, Wojciech Kudyba, Przemysław Dakowicz).

Czym się charakteryzuje gorczański genius loci?

Kto choć raz w życiu nie oddychał górskim, a polskim powietrzem, kto go nie skosztował z przyprawą świeżości porannej, ten nigdy nie pojmie tej tajemniczej, błogosławionej władzy, jaką góry wywierają na wszystkie zmysły, czucia, na całą istotę człowieka; zdaje się, że przyroda rozkochana we wdziękach Boga, weselsza tutaj niż gdzie indziej, swobodniejsza, udziela swojego szczęścia każdemu, co na równi z nią Boga czuć potrafi ${ }^{8}$.

Gorce nie zasługują na lekceważenie. Alpinista i teolog ks. Roman Rogowski akcentował: „liczy się każda góra”. Obrazami malowanymi na szkle miał się zachwycać nawet Pablo Picasso (według przewodnika Gorce). Bez wątpienia dostępna żyzna gleba i stosunkowo łagodny klimat sprzyjały osadnictwu, co symbolicznie da się zinterpretować jako przejawy bożej przychylności dla ludności Gorców. Urzekająco, wręcz baśniowo brzmi opis lasu w Gorcach:

Runo może korzystać ze światła słonecznego tylko do czasu, aż rozwiną się liście buków. Dlatego wiele roślin wykształca pąki kwiatowe jesienią lub pod śniegiem, aby jak najwcześniej rozpocząć wegetację. Okres kwitnienia jest krótki, odbywa się w bardzo szybkim tempie. Z początkiem lata na dnie lasu nastaje półmrok i cykl życiowy tych roślin kończy się, łodygi i liście obumierają, a pozostają tylko części podziemne ${ }^{10}$.

Tam, gdzie wychowywał się jako dziecko przyszły słynny ksiądz-myśliciel, jedna z najsławniejszych postaci Polski XX wieku związanych ze Starym Sączem, ks. Józef Tischner, autorytet egzekwowano „ze względu na robotę”, a zarazem w kontakcie z przyrodą, która niejako weryfikowała wartość ludzkiej pracy ${ }^{11}$. Historia II wojny światowej z gorczańskiej perspektywy potwierdza wynikającą z fizycznego ukształtowania terenu prawidłowość, że walczący z przemożną siłą okupanta partyzanci z reguły szukają wsparcia pod osłoną gór. Z kolei do najnowszych dziejów Polski należą nabożeństwa odprawiane w okolicach Turbacza przez duszpasterza młodzieży Karola Wojtyłę, a także wygłaszane później pod-

${ }^{8}$ S. Goszczyński, Dziennik podróży do Tatrów, powstałe w 1832 roku, druk całości: Petersburg 1853, cyt. za: Gorce. Przewodnik, Pruszków 2011, s. 13. Zob. M. Grabowska, Dziennik podroży do Tatrów, [w:] Literatura polska. Przewodnik encyklopedyczny, t. 1, red. J. Krzyżanowski, C. Hernas, Warszawa 1991, s. 228-229.

9 R. Rogowski, op. cit., s. 20.Z Księgi Mądrości: „Bo we wszystkim jest Twoje nieśmiertelne Tchnienie [12, 1]. Przede wszystkim jest ono w górach [— kontynuuje ks. Rogowski — D.H.]. Toną w Duchu Świętym jak szczyty skalistych wysp w wodach Halongu" - ibidem.

10 W. Kudyba, Gorce Pana, Sopot 2007, s. 26.

11 Zob. W. Bonowicz, Ks. Józef Tischner, Warszawa 2001, s. 35. 
czas przyjazdów do kraju papieskie homilie na Ziemi Sądeckiej, w Beskidach, na południu kraju.

Według Gastona Bachelarda

$\mathrm{Na}[\ldots]$ szlaku szczęścia rozpościerają się [...] kosmosy pośrednie, te na przykład, które opisywał w L'Espace poétique (Przestrzeń poetycka), a szczególnie uprzywilejowany mikrokosmos, ów kosmos zhumanizowany przez pracę i ludzkie marzenie; dom, siedziba człowieka, „od piwnicy aż po strych" streszczająca symbole świata w swych kamieniach, belkach, kominkach, w swych studniach, w swych ciemnych i wilgotnych piwnicach, w suchych i przewiewnych poddaszach ${ }^{12}$.

Dla Wojciecha Kudyby Gorce są w pewnym sensie domem. Jawią się one zarazem Domem Pańskim, czyli miejscem epifanii. Jak trafnie skonstatował Adrian Gleń,

Wbrew sceptykom, cynikom, ateistom, agnostykom i filozofom, którzy mówili, że owszem, że może (ale raczej chyba nie), ale że to bez znaczenia. Że nikt nie może nas uratować. Że nie ma nas kto uratować. Że nawet jeśli jest, to i tak jako causa sui, bóg-konstrukt, przed którym nijak śpiewać i tańczyć nie wypada.

Przychodzi.

Przychodzi, a nie — zjawia się „na wozie wichru”. Przychodzi, jak przychodzi. Przyjaciel. Przychodzi tak, jak dla Różewicza odchodził. Jak polna myszka, jak woda, która bezszelestnie wsiąka w piach. W tej teofanii nie ma tremendum, nie ma majestas! (Zdecydowanie bliżej bohaterom wierszy Kudyby do doświadczania Boga podczas pełnego uniesienia, zachwytu i radości, świątecznej fascynacji; wówczas i Bóg przychodzi bliżej, jak w pięknym zimowym tańcu w Sykstynie. Kulig czy w urzekającej prostotą dziecięcej zabawie z Widoku ze Sralówek do doliny ucichtej) $)^{13}$.

Efekt artystyczny nie stanowi dla Kudyby celu samego w sobie. A przecież efekt ten uzyskuje. Kryteriami oceny, którym jego poezja odpowiada, są harmonia, umiar i dobry gust. Zamiast modnego szokowania transgresją - uszanowanie dla rytmu tradycji: następstwa świąt, pór roku, naturalnych etapów ludzkiego życia. Podmiot wiersza Kowaniec zapewnia czytelnika:

To, co nas zmienia - jasny potok, woda

W żeliwnych rynnach, w iskrach

Rubinowych rowach

Podziemna rzeka, która nas nurtuje

Łagodzi głazy, kuje z wielkim trudem

12 Cyt. za: G. Durand, Wyobraźnia symboliczna, przeł. C. Rowiński, Warszawa 1986, s. 87.

13 A. Gleń, Krytyka i metafizyka. Studia i szkice o najnowszych zjawiskach i tekstach literackich, Sopot 2017, s. 155. 
Stal, mikę skaleń, nieustannie toczy

Przez wioski, jary, krajobrazy, kraje

Odwrócone na drugą stronę

Inne, niepojęte.

To, co w nas tkwi - ta zadra

Wciąż dotyka, męczy

To, co zostaje, nie daje spokoju

Czuwa w kamieniach

Na skraju ogrodu

Na wielkiej grani, na granicy

Coś, co jest ciszą

Coś, co głośno krzyczy ${ }^{14}$.

Z jednej strony, duchowość chrześcijańska zdaje się kłaść nacisk na indywidualizm jednostkowego sumienia, samotnej modlitwy nie na pokaz, nie w tłumie oraz na wolność osoby ludzkiej. Z drugiej strony, pożądane postawy etyczne, takie jak miłość bliźniego, służba, wyrzeczenie się egoizmu i egocentryzmu, urzeczywistniają się, rozwijają, weryfikują we wspólnocie. Dlatego też w silnie zabarwionej ewangelicznymi motywami poezji powtarza się zaimek „my”, stale powracają formy pierwszej osoby liczby mnogiej, egzystencja wpisana jest w ramy życia rodzinnego, a na wycieczkę zwykle idzie się w towarzystwie, jak w wierszu Żal:

Mieliśmy iść na Gorc, lecz w środku drogi

Chwycił nas deszcz - zatrzymał w nocy srogiej

Dusznej szeleścił, szeptał, szył, namawiał szumem

Chował w szałasach, okrywał całunem

Mchów, porywał nagle w wichrze krętym

W lotne obłoki, okrągłe odmęty

W szalonym graniu, w tańcu, w fujawicy

W dziurawcach, rdestach, w złotych błyskawicach

Mieszał nas z trawą, z błotem, pstrym poszyciem

Wodził, oczyszczał, nęcił, szeptał skrycie

Że w jednej chwili, nie wiadomo kiedy

Zabierze nas do siebie, wyrwie z ziemi...

Wyraźnie tracił głowę, zaplątany

Chyba nas mylił z kimś innym, strugami

Płynęły ciężkie wody pod Turbaczem

I płynął po nas deszcz, który był płaczem ${ }^{15}$.

Typologie wiązać by się mogły z biblijną historią. Jak porządkował kiedyś staro- i nowotestamentową „mistykę gór” ks. Roman Rogowski:

14 W. Kudyba, W końcu świat..., s. 45.

15 Ibidem, s. 56. 
Ararat — góra nadziei i ocalenia zrodzonego z klęski

Moria - Sanktuarium i góra próby i ofiary

Synaj — Góra Objawienia, fascynacji i wiary

A także:

[w ogóle] góry nawiedzenia — Duch, miłość i solidarność

Góra Kuszenia - wolność, pokora i zwycięstwo

Góra Błogosławieństw — góry uszczęśliwiające

Tabor — góra przemienienia, mistyki i wierzenia

Góra Oliwna - modlitwa, wierność i wniebowstępowanie

Golgota — góra przemijania i śmierci prowadzącej do życia

Syjon — „niebo nowe i ziemia nowa” — i nowe góry ${ }^{16}$.

Doświadczony teoretyk literatury, specjalizujący się w zagadnieniach aksjologicznoliterackich, Stefan Sawicki poświęcił Gorcom Pana oddzielną analityczną pracę, zatytułowaną „Gorce Pana” Wojciecha Kudyby, czyli próba neosymboli$z m u$. Uczony ocenił wysoko Gorce Pana, ponieważ

ten sposób pisania, poetycko wcielający wiarę, warto potraktować jako propozycję dla współczesnej liryki religijnej [...]. Jest [...] bliski wrażliwości wielu ludzi, których na spotkanie z Panem prowadzi uważne, miłujące wpatrywanie się w ten świat ${ }^{17}$.

Przede wszystkim Sawicki położył nacisk na niezwykle intensywne nasycenie zbioru geograficznymi oraz przyrodniczymi realiami. Ponad nimi panuje transcendentna rzeczywistość, którą literaturoznawca określił „Miłoszową »druga przestrzenią《" $" 18$.

Wnikliwe spostrzeżenia Sawickiego ukazują ścisłe znaczenie poszczególnych toponimów w kontekście danych utworów, przykładowo Kowaniec to potok w Gorcach, a zarazem symboliczne poszerzanie pola semantycznego - na przykład woda nie tylko pochodzi ze źródła, lecz także „spływa z obłoków”19, usymbolicznienie zaś dokonuje się w rezultacie wspólnoty wielorako funkcjonalnych motywów akwatycznych w świecie przyrody i kultury. Motywika ewokująca zmienność nurtu pozwala ująć tyleż realny potok, ile głębię rzeczywistości życia duchowego, wewnętrznego. Szelesty, szmery, delikatne drżenie listka badacz porównuje do głosu sumienia. Usymboliczniają się w tomiku zwłaszcza ciche, skromne obiekty: listki właśnie, patyczki, źdźbła, pyłki, okruszyny, igiełki, podatne na określanie deminutywne. W ten sposób — dodajmy — potęguje się kontrast między kruchością stworzenia i potęgą Stwórcy.

Z kolei analiza Pieśniczki o dzikiej róży akcentuje symboliczną jedność kultury i natury, sięgającą tego, co nadprzyrodzone. Podobne uogólnienia dzięki hi-

16 R. Rogowski, op. cit., s. 155.

17 S. Sawicki, „Gorce Pana” Wojciecha Kudyby, czyli próba neosymbolizmu, [w:] idem, Wartość - sacrum - Norwid. Studia i szkice aksjologicznoliterackie, Lublin 2017, s. 138.

18 Ibidem, s. 129.

19 Ibidem, s. 130. 
perbolizacji pozwalają ze szczegółowych obserwacji zwykłych realiów przejść w wierszach Pasterka na Rusnakowej, Gorc, Idzie dysc, Ochotnica i Solnisko zobrazować wiarę w pielgrzymowanie ludzi do Boga, niejako w pielgrzymkę do domu Ojca. Bóg, synonimicznie nazywany „Pan” lub „On”, objawia się według symbolicznego kodu jako wiatr.

Sawicki najwyżej waloryzował utwory, które zawierają fragmenty ekfraz: Sykstyna. Kulig (,Złocenia Kaplicy Sykstyńskiej przemieniają się w odcienie szronu, dynamika postaci i zdarzeń utożsamia się z wirami górskich rzek, obłoki nabierają konkretności" ${ }^{20}$ ) oraz Wóz siana i Marnotrawny (ekfrazy obrazów Hieronima Boscha). Związek sztuki, literatury i wiary niejednokrotnie przypominał też autor Listu do artystów, patron KUL, a jego przyszły następca mówił swego czasu w Watykanie:

Sztuka jest czymś elementarnym. Sam rozum, w tej postaci, która przejawia się w nauce, nie może stanowić pełnej odpowiedzi człowieka na rzeczywistość i nie potrafi oddać tego wszystkiego, co człowiek może, chce i musi wyrażać. Myślę, że to Bóg tchnął sztukę w ludzkie dusze ${ }^{21}$.

Zmierzając ku ostatecznym wnioskom, trzeba zauważyć religijne podstawy tej poezji. Innymi słowy, w stylu filozofii Emmanuela Lévinasa i jego szkoły, w młodszym pokoleniu literaturoznawców pojawiła się następująca refleksja:

(Może to jest najwyższa stawka, o jaką idzie w poetyckiej grze? Taką pod-powiedź pod-szepnąć dyskretnie, tak urzec czytającego, by ten wskrzesił w sobie owo głębokie pragnienie, na powrót i na dalszą drogę?...). To musi być ślad, drzazga. Urwany szept. Wiersz Kudyby jest medytacją o tym, jak nastroić się na Przyjście 22 .

Identyfikacja środków artystycznego wyrazu nie powinna być celem samym w sobie. U Kudyby dążenie do piękna zawarte w kontemplacyjnym w pogłębianiu wrażliwości prowadzi zazwyczaj do porównania drogi, zarówno mentalnej, jak i empirycznej, ze sztuką; na przykład w takiej wizji multimedialnej:

Poczuć jak niesie - niczym wielki, atlantycki wiatr:

Zawsze do wewnątrz.

Ruch bywa wtedy tańcem

Wędrówka - słuchaniem.

Wiele podróży ma taki charakter: muzyczny ${ }^{23}$.

Odnotować wypada więcej możliwości interpretacyjnych poezji Kudyby niż tylko jej odbiór jako pogodnej wizji świata zmierzającego do zbawienia. W pod-

20 Ibidem, s. 133.

21 J. Ratzinger, Sól ziemi. Chrześcijaństwo i Kościół katolicki na przełomie tysiącleci, rozm. P. Seewald, przeł. G. Sowiński, Kraków 1997, s. 4.

22 A. Gleń, op. cit., s. 155.

23 W. Kudyba, W końcu świat..., s. 35. 
tekście bowiem zachodzi niebezpieczeństwo przewartościowania jasnego, pogodnego obrazu rzeczywistości jako wziętego w ironiczny nawias marzenia. Czytelnik pozostaje w rezultacie bez żadnej pewności, tylko z wiarą i nadzieją, że się nie mylił, ufając harmonijnemu współistnieniu miłości rodzinnej, ciągłości tradycji literackiej i domowej, a zarazem powszechnej, religii. Motywy gór, w szczególności Gorców, rodziny, domu uzyskują rangę uniwersalnej topiki. Ta harmonia bywa jednak postawiona pod znakiem zapytania przez ewentualność autoironii, z jednej strony, owocuje właśnie - poszukiwanym przez poetę - efektem poruszonej formy. Z drugiej zaś — znaczenia są stabilizowane dzięki naciskowi położonemu na kluczowe znaczenie epifanii w ludzkiej rzeczywistości, weryfikowanej przez zgodność z trwaniem naturalnego porządku świata przyrody, piękna pejzażu, wyzwania dla charakteru i sprawności fizycznej człowieka, jakie stanowią góry. Mistyczne doznanie spotkania się z Bogiem należy do motywów powtarzających się w podróżniczych relacjach. Jak pisał alpinista i uczony ks. Roman Rogowski,

wierność-skała (Iz 25, 4-5) jest najgłębszym motywem ufności pokładanej w Bogu. Ile razy więc stoję twarzą w twarz ze skalnym światem gór, czy to będą Dolomity czy Galdhöpiggen, masyw Phang-Si-Pang czy Karkonosze, tyle razy budzi się we mnie skojarzenie z nadzieją, z zawierzeniem, z wiernością Boga, który jest Skałą Ocalenia, bo kiedyś na górze Ararat ocalił rodzaj ludzki i zapewnił o swojej wierności ${ }^{24}$.

Wojciech Kudyba traktuje Gorce bardziej jako przestrzeń interakcji międzyosobowych, a ściślej — jako rzeczywistość rodzinnych więzi, niż jako pejzaż. Na inne kwestie zwracali uwagę eseiści: Jacek Woźniakowski w Górach niewzruszonych, dla którego liczyły się jedynie pejzaż i sztuka, a także ks. Roman Rogowski w Mistyce gór, dla którego właściwie liczył się jedynie Bóg bądź — co najwyżej — droga człowieka do zbawienia. Szczególna książka, a zarazem cykl poetycki, czyli Gorce Pana, to przykład oryginalnej, odważnej liryki religijnej. Pogodny ton przypomina renesansowe wzorce pobożności. Religijność wyrażana jest za pomocą przyrodniczej metaforyki.

\section{Bibliografia}

\section{Źródła}

Kudyba W., Gorce Pana, Sopot 2007.

Kudyba W., Ojciec się zmienia, Sopot 2014.

Kudyba W., Słowa bliskie, Kraków 2003.

Kudyba W., Tyszowce i inne miasta, Sopot 2005.

Kudyba W., W końcu świat, Sopot 2014.

Kudyba W., Wierność w małej rzeczy, Lublin 1992.

Kudyba W., Wiersze dla księdza Jana i innych bliskich osób, Nowy Sącz 1999.

${ }^{24}$ R. Rogowski, Mistyka gór, Wrocław 1983, s. 34. 


\section{Opracowania}

Balcerzan E., Poezja polska w latach 1939-1965, cz. 1. Strategie liryczne, Warszawa 1984.

Balcerzan E., Poezja polska w latach 1939-1965, cz. 2. Ideologie artystyczne, Warszawa 1988.

Bernacki M., Caty świat Wojciecha Kudyby, „Topos” 2015, nr 2.

Bernacki M., ,,Rozmowa z Nim jest jak podróż — zawsze w innym miejscu” — o poezji Wojciecha Kudyby, „Polonistyka” 2006, nr 1.

Durand G., Wyobraźnia symboliczna, przeł. C. Rowiński, Warszawa 1986.

Dybciak K., Trudne spotkanie. Literatura polska XX wieku wobec religii, Kraków 2005.

Eliade M., Sacrum a profanum. O istocie sfery religijnej, przeł. B. Baran, Warszawa 2008.

Fryz A., Krytyk wobec innego. Na marginesach ksiażki Wojciecha Kudyby Wiersze wobec innego, „Topos” 2012, nr 5.

Garbol T., Nastuchiwanie, „Topos” 2015, nr 1.

Garbol T., Rehabilitacja literatury, „Ethos” 2013, nr 4.

Gleń A., Krytyka i metafizyka. Studia i szkice o najnowszych zjawiskach i tekstach literackich, Sopot 2017.

Gleń A., ,,Przyjście” (wiersz Wojciecha Kudyby), „Topos” 2011, nr 6.

Gleń A., Świat to za mało... Glosy do poezji Wojciecha Kudyby, „Topos” 2012, nr 5.

Gleń A., ,Zostań, czuwajmy — ptonie ogień...”-Wojciecha Kudyby Gorce Pana (Notatki osobiste), „Topos” 2008, nr 4.

Gorce. Przewodnik, Pruszków 2011.

Grabowska M., Dziennik podroży do Tatrów, [w:] Literatura polska. Przewodnik encyklopedyczny, t. 1, red. J. Krzyżanowski, C. Hernas, Warszawa 1991.

Kass W., Ręka piszaca (1), [w:] Konstelacja Topoi o rzeczach najważniejszych, red. A. Gleń, Sopot 2017.

Kociuba G., Próba catości, „Fraza” 2015, nr 2.

Kwiatkowski J., Wizja przeciw równaniu. Nowa walka romantyków z klasykami, „Życie Literackie” 1958, nr 3.

Łukasiewicz J., O wierszach Wojciecha Kudyby, pamflecie i upale, „Odra” 2014, nr 9.

Puzynina J., O poruszajacej poezji Wojciecha Kudyby, „Poradnik Językowy” 2013, nr 5.

Ratzinger J., Sól ziemi. Chrześcijaństwo i Kościót katolicki na przełomie tysiącleci, rozm. P. Seewald, przeł. G. Sowiński, Kraków 1997.

Rogowski R., Mistyka gór, Wrocław 1983.

Sawicki S., „Gorce Pana” Wojciecha Kudyby, czyli próba neosymbolizmu, [w:] idem, Wartość sacrum — Norwid. Studia i szkice aksjologicznoliterackie, Lublin 2017.

Szczepan-Wojnarska A.M., Nad wierszami Wojciecha Kudyby Tyszowce i inne miasta, „Topos” $2005, \mathrm{nr} 3$.

Szymik J., Stowo do Czytelnika, [w:] W. Kudyba, Słowa bliskie, Kraków 2003.

Zarębianka Z., Kim jest ojciec? Sakralny wymiar relacji w nowych wierszach Wojciecha Kudyby, „Topos” 2012, nr 6.

Zarębianka Z., ,,Miejsca święte” w wierszach Wojciecha Kudyby, „Dekada Literacka” 2007, nr 5-6. 